\title{
The University of Chicago Press
}

\section{THE PHYSICAL AND MENTAL GROWTH OF}

PREMATURELY BORN CHILDREN 22s. $6 d$. net

By Julius H. Hess, George J. Mohr and Phyllis F. Bartelme

"This book probably contains more original research and statistical data than any other book on the subject...."-Journal of the American Medical Association.

\section{ULTRAVIOLET LIGHT AND VITAMIN D IN NUTRITION \\ 11s. $6 d$. net}

By Katharine Blunt and Ruth Cowan. A surveyof all vitamin D discoveries, including creation of its effects by ultraviolet light.

DIET AND EFFICIENCY. A Five-Year Controlled Experiment on Man.

4s. $6 d$. net By HARALD G. O. Holck. Objectiveevidence of the effects of certain eating habits.

THE EPIDEMIOLOGY AND CONTROL OF MALARIA IN PALESTINE

22 s. $6 d$. net

By I. J. KLIGLER. A complete account of successful control measures.

\section{CHILDBIRTH}

13s. 6 d. net

By William G. Lee, M.D.

\section{NUTRITION WORK WITH CHILDREN (Revised} edition)

13s. 6d. net

By Lydia J. Roberts. A splendid survey of the subject of malnutrition,- - of its causes, effects, prevention, and treatment.

\section{THE NEWER KNOWLEDGE OF BACTERIOLOGY AND IMMUNOLOGY \\ 45s, net}

Edited by E. O. JordAN and I. S. FALK. A collection of late researches in the field of bacteriology prepared by the leading eighty research men in the field.

\section{LABORATORY OUTLINES IN BACTERIOLOGY AND IMMUNOLOGY \\ $7 s .6 d$. net \\ By JoHṆ F. NORTON and I. S. FALK}

FOOD: POISONING (Revised edition) 11s. $6 d$. net By EDWIN O. JORDAN

AGENTS IN GREAT BRITAIN AND THE BRITISH EMPIRE (EXCEPT CANADA) Cambridge University Press, Fetter Lane, London, E.C. 4 


\section{O N T E N T S}

(All rights reserved)

HALDANE, JOHN SCOTT

Widpowson, E. M. A Study of English Diets by the Individual Method. Part I. (With I Figure)

Wimdowson, E. M. and McCAnce, R. A. A Study of English Diets by the Individual Method. Part II. (With 1 Figure)

Henry, S. A. and Invine, E. D. Cancer of the Serotum in the Blackbum Registration District, 1837-1929 .

Fatrlex, A., Linton, E. C. and Ford-Moore, A. H. Note on the Toxicity to

Animals of some Oxidation Produets of 1:4 Dioxan .

EDwards, Phmip R. Serological Variants of Salmonella typhi-murium with

special reference to $S$. typhi-murium var. Binns.

A BDoosh, Y. B. Natural and Immune Bactericidins for the Gonococcus . $\quad 355$

BAмтовтн, J. A Gas-producing Variety of Bacterium allalescens (Andrewes) 363

Horgan, E. S. Notes on the Vi Antigen of Bacillus typhosus .

Russert, W. T. Statistical Study of the Sex Ratio at Birth. (With 1 Diagram)

Martin, W. J. Studies in the Declining Birth-rate, Wales and South England.

(With 2 Maps)

Smith, J. and Davidson, L. S. P. The Incidence of Weil's Disease in Fish

Workers in Aberdeen

Blatr, E. MAUd MoV. Boric Acid as a Selective Bacteriostatic Agent .

Munir EL-GazayerLI. Note on the Incidence of Intrathoracic Tumours in

Edinburgh Royal Infirmary .

Scholtens, R. Tн. The Resistance Developed against Bacteriophage .

Pulutnger, E. J. The Influence of Tuberculosis upon the Development of

Brucella abortus Infection

The Journal of Hygiene is issued as material accumulates. A volume containing four numbers is issued annually in paper covers at the following net prices:

Volumes I-III (1901-3). 17s. 6d. net per volume.

Volumes IV-XVI (1904-18), excepting Vol. VI, no. 4, Plague number. $25 s$. net per volume.

Volume XVII (1918). 31s. net.

Volumes XVIII-XXXI (1919-31). 42s, net per volume.

Volumes XXXII-XXXV (1932-35). 47s. 6d. net per volume.

Quotations can be given for buckram binding cases and for binding subscribers' sets; also for bound copies of back volumes.

Papers for publication may be sent to Prof. Geo. H. F. NutraLt, F.R.S., Longfield, Madingley Road, Cambridge, or to the associate Editors. Other communications should be addressed to the University Press, Cambridge.

Papers forwarded to the Editors for publication are understood to be offered to The Journal of Hygiene alone, unless the contrary is stated.

Contributors receive fifty copies of their papers free. Additional copies may be had at cost price: these should be ordered when the final proof is returned.

The subscription price is $£ 2.78$. 6d. per volume (post-free), payable in advance; single numbers $14 s$. $0 d$. net. Subscriptions may be sent to any Bookseller, or to The Cambridge University Press, Fetter Lane, London, E.C. 4.

The Cambridge University Press has appointed the University of Chicago Press agents for the sale of The Journal of Hygiene in the United States of America. 